\title{
ALTERNATIF PENDIDIKAN NON FORMAL DALAM MENINGKATKATKAN AKHLAK PADA ANAK MELALUI PENDIDIKAN BERBASIS MASJID (MADRASAH DINIYAH/SEKOLAH AGAMA)
}

\author{
Eddy Saputra \\ Program Studi Informatika, Universitas Indraprasta PGRI \\ Email: saputra2578@gmail.com
}

\begin{abstract}
Abstrak
Perubahan tingkah laku merupakan salah satu tujuan dari proses pendidikan. Tingkah laku dalam Islam disebut dengan akhlak. Akhlak atau dalam bahasa Indonesia disebut dengan karakter, dimana prilaku manusia dapat dibentuk melalui proses pendidikan agar menjadi pripadi yang lebih baik. Pendidikan tidak saja berbasis formal ada juga pendidikan non formal dan ini biasanya sering diselenggarakan di masjid. Selain dijadikan tempat ibadah masjid juga dapat dijadikan tempat belajar agama yang tujuannya untuk memberikan pemahaman tentang nilai-nilai keislman yang minim disampaikan disekolah formal. Tujuan dari ilmu agama disampaikan untuk menjadikan anak-anak memilki kepribadian yang baik yaitu akhlakul karimah. Akhlak anak-anak dibina dan ditingkatkan melalui pendidikan berbasis masjid yakni pendidikan dimana materinya tentang agama yang diajarkan di masjid. Penulisan ini menggunakan penelitian kualitatif, dikarenakan penelitian berdasarkan pengamatan dilapangan. Tujuan penulisan agar anak-anak mau belajar ilmu agama yang diselenggarakan di masjid biasa juga disebut Madrasah Diniyah atau sekolah agama.
\end{abstract}

Kata kunci: Pembinaan, Peningkatan Akhlak, Pendidikan Berbasis Masjid

\begin{abstract}
Changes in behavior are one of the goals of the education process. Behavior in Islam is called Akhlaq. Akhlaq in Indonesian is called character, where human behavior can be formed through the process of education in order to become a better person. Not only formal-based education there is also non-formal education and this is usually often held in mosques. Besides being used as a place of worship, a mosque can also be used as a place of religious study, the aim of which is to provide an understanding of Islamic values that are minimal in formal schools. The purpose of religious knowledge is conveyed to make children have a good personality that is akhlakul karimah. The morals of children are fostered and enhanced through mosque-based education where the material is about religion taught in the mosque. This writing uses qualitative research, because research is based on field observations. The purpose of writing is making children want to learn the science of religion which is held in a regular mosque. This kind of education is usually called Madrasah Diniyah or religious school.
\end{abstract}

Keywords: Coaching, Moral Improvement, Mosque-Based Education

\section{PENDAHULUAN}

Pendidikan merupakan suatu proses yang mencakup tiga dimensi, individu, masyarakat, atau komunitas nasional dari individu tersebut dan seluruh kandungan realitas bail material maupun spiritual yang memainkan peranan dalam menentukan sifat, nasib, bentuk manusia maupun masyarakat [1]. Pemerintah dalam hal ini begitu konsen dalam menyediakan sarana pendidikan bagi masyarkatnya sekalipun belum bisa dikatakan maksimal akan tetapi upaya pemerintah begitu serius dalam aspek pendidikan. Pemerintah daerah berlomba untuk memberikan layanan pendidikan gratis sampai dengan jenjang Sekolah Menengah Atas, belum lagi tunjangantunjangan lainnya. Ini semua dilakukan agar seluruh lapisan masyarkat dapat merasakan dunia pendidikan.

Kebutuhan akan dunia pendidikan tidak hanya sebatas pada yang formal ( pendidikan yang diselengkarakan oleh 
pemerintah atau swasta yang memilki kurikulum dan tempat yang khusus) juga ada pendidikan yang non formal. Philip H.Coombs berpendapat bahwa pendidikan non formal adalah setiap kegiatan pendidikan yang terorganisir yang diselenggarakan diluar system formal, baik tersendiri maupun merupakan bagian dari suatu kegiatan yang luas, yang dimaksudkan untuk memberikan layanan kepada sasaran didik tertentu dalam mencapai tujuan-tujuan belajar [2].

Masjid sebagai tempat ibadah kaum muslimin sekaligus dapat menjadi tempat mempererat umat. Realitanya dewasa ini banyak kehilangan perannya sebagaimana mestinya. Pada zaman Nabi Muhammad SAW pada awal pembangunannya masjid dijadikan sebagai pusat kegiatan agama. Bahkan kegiatan yang berkaitan pada masyarakat dan Negara sering diadakan di masjid. Masjid dijadikan tempat berkumpul untuk membahas strategi perang, diskusi dan dakwah, selain disediakan sebagai sarana untuk beribadah yang merupakan esensi dari peran masjid itu sendiri [3]. Dalam sejarah Indonesia masjid menjadi sarana pendidikan awal sebelumnya adanya pendidikan formal, masjid sering dijadikan tempat yang utama dalam memberikan pelajaran pada anak bangsa ketika itu.

Dinamika masjid-masjid sekarang banyak yang mengikuti dengan perkembangan teknologi. Artinya, masjid selain berperan sebagai tempat ibadah, juga menjadi wadah beraneka macam kegiatan umat Islam. Sebab, masjid merupakan identitas dan kebanggaan umat islam. Dengan demikian, peranan masjid tidak hanya menitik beratkan pada pola aktifitas yang bersifat akhirat, tetapi memadukan antara aktifitas ukhrawi dan aktifitas duniawi [4].
Anak merupakan aset bangsa dalam melanjutkan perjuangan untuk membangun negeri. Oleh karena itu orang tua memiliki kewajiban untuk memberikan pendidikan yang sesuai dengan tujuan agama dan bangsa. Pengenalan nilai-nilai keislaman harus dikenalkan sejak dini agar anak-anak meemahami, dengan faham maka akan mengasilkan output akhlak yang baik, ketika pendidikan akhlak tidak banyak didapat disekolah maka masjid menjadi ujung tombak untuk menutupi kurangnya pelajaran akhlak di sekolah. Banyak sudah motede atau jenis pendidikan berbasis masjid diantaranya Taman Pendidikan anak (TPA) atau Taman Pendidikan Al qur'an). Dalam Hadist Rosullulah.

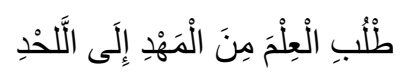

"Carilah ilmu sejak dari buaian hingga ke liang lahat". (Al Hadits)

Hadits ini menjelaskan bahwa belajar harus berkesinambungan, maka jika merujuk pada hadist ini potensi belajar secara non formal lebih banyak porsinya dibandingkan dengan formal. Pendidikan formal jika ditempuh sampai jenjang strata 1 hanya membutuhkan waktu normal 16 tahun sementara pendidikan yang non formal sudah dimulai sebelum sekolah, pada masa sekolah serta dilanjutkan setelah selesai sekolah, sampai pada akhirnya pembelajaran itu baru benhenti berbarengan dengan wafatnya kita.

$$
\text { أُطْلُبُوْ العِلْمَ وَلَوْ في الصِيّين }
$$

"Tuntutlah ilmu walaupun sampai ke negeri China."

Kalimat negeri China dalam hadits mengambarkan setiap manusia harus memiliki semangat dalam belajar, sekalipun tempat mereka belajar memiliki jarak yang jauh. Secara subtansial hadits ini memberikan motivasi bagi kita agar 
memiliki semangat belajar tanpa dibatasi kendala apapun.

Memaksimalkan potensi masjid sebagai media pendidikan pada anak secara tidak langsung mengenalkan anak pada ajaran agama serta identitas agamanya. Materi pembelajaran bisa dikemas baik langsung maupun praktek. Penanaman akhlak pada anak secara perlahan bisa diberikan, gurupun bisa dengan mudah memantau perkembangan anak dari hari-kehari. Pembelajaran yang tidak bergantung pada sistem kalender akademik membuat anakanak lebih banyak menghabiskan waktu belajar dimasjid, terlebih ketika sekolah formal libur, maka masjid dapat menjadi solusi untuk melanjutkan program belajar pada anak. Mengapa pendidikan anak harus diselenggarakan dimasjid, masjid tentu kurikulumnya berbasis keislaman, dan ini menjadi berbeda dari pendidikan anak umum yang banyak dikelola oleh kelompok masyarakat. Pendidikan anak berbasis masjid menekankan pada pembentukan generasi Muslim di masa mendatang (regerasi), dengan cara pembiasaan atas nilai-nilai Islam. Regenerasi ini dilakukan bertujuan untuk menjadikan masyarakat yang Islami karena inilah yang diharapkan dalam Islam. Melalui pendidikan anak berbasis masjid inilah diharapkan muncul karakter Islamiah, yang mampu merubah keadaan negatif menjadi positif [5].

\section{METODE}

Metode penelitian pada Alternatif pendidikan non formal dalam meningkatkan akhlak pada anak melalui pendidikan berbasis masjid, maka peniliti menggunakan motodologi kualitatif. Artinya data yang dijadikan sebagai acuan bukan berupa hitungan angka, pengamatan lapangan, dan catatan resmi lainya, sehingga yang menjadi tujuan dari penelitian kualitatif ini adalah ingin menjelaskan keadaan yang sebenarnya dibalik fenomena yang terjadi didalamanya secara rinci dan tuntas. Oleh karena itu penggunaan pendekatan kualitatif dalam penelitian ini adalah dengan mencocokan antara realita empirik dengan teori yang berlaku dengan menggunakan metodologi kulaitatif deskriftif [6].

Pendekatan kualitatif dapat menghasilkan penjabaran atau uraian tentang perkataan, prilaku dan sikap dari individu atau kelompok masyarakat. Kemudian diamati sehingga dapat mengahasilkan sebuah kesimpulan dasar. Penelitian kulitatif bertujuan mendapatkan pemahaman yang umum terhadap keberadaaan yang terjadi di tengah masyarakat.

Teknik pengumpulan data berdasarkan observasi yang terjadi dilingkungan masjid. agar peneliti benar-benar mendapatkan data yang sesungguhnya, sehingga data dapat di jelaskan dan disajikan merujuk kepada kejadian yang benar-benar terjadi di lapangan. Sumber data yang di hasilkan dari beberapa informan yang terlibat aktif maupun pasif dalam kegiatan proses belajar mengajar yang ada di masjid. Observasi atau pengamatan dilakukan melalui media CCTV yang terpasang dimasjid. Metode yang digunakan melalui observasi secara langsung terhadap beberapa kegiatan belajar mengajar anak di masjid.

Analisis data adalah proses mengorganisasikan dan mengurutkan data ke dalam pola, kategori, dan satu uraian dasar sehingga dapat ditemukan tema dan dapat dirumuskan hipotesis kerja seperti yang disarankan oleh data. Analisis data merupakan proses mengolah, memisahkan, mengelompokan, dan memadukan sejumlah data yang akan dikumpulkan dilapangan secara empiris menjadi sebuah kumpulan informasi ilmiah yang terstruktur dan 
sistematis [7]. Data diambil melalui pengamatan dan perubahan sikap pada anak.

\section{HASIL DAN PEMBAHASAN}

\section{Masjid Sebagai Pusat pembelajaran}

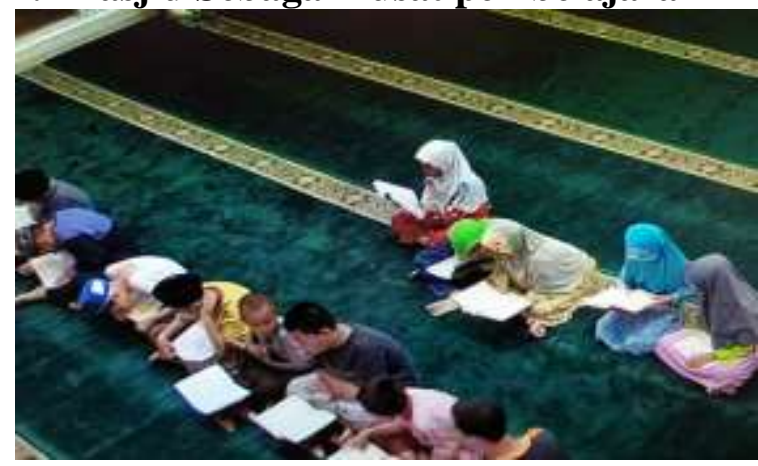

Gambar 1: Anak-anak belajar dimasjid

Kegiatan mengaji ini dilakukan secara rutin oleh anak-anak, bahkan nyaris setiap harinya, hanya hari ahad mereka libur. Masing masing anak memegang Al Qur'an lalu mereka membaca ayat satu persatu kemudian ustad akan membenarkan apa yang mereka baca baik dari segi huruf dan hukum bacaaannya.

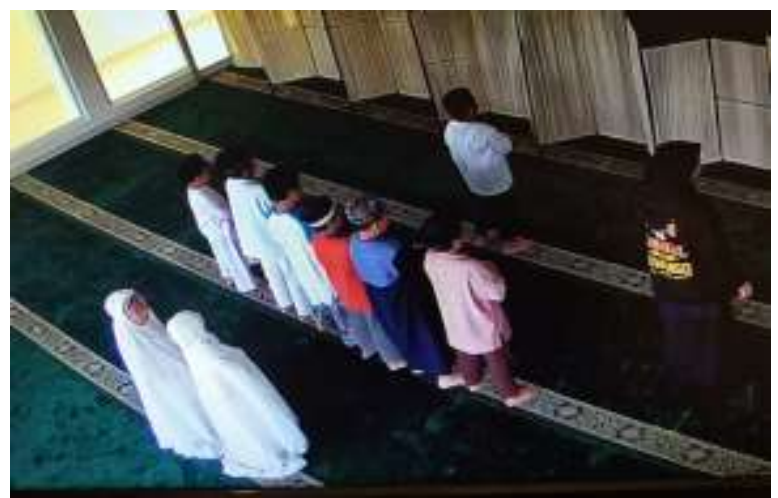

Gambar 2: Anak-anak praktek sholat

Dalam gambar ini anak-anak sedang praktek Sholat, ini merupakan bagian materi materi ilmu fiqh dan langsung di praktekan di masjid. Kedua gambar tersebut memberikan informasi, bahwa anak-anak menghabiskan waktu untuk belajar ilmu agama dimasjid, (Pendidikan berbasis masjid atau madrasah diniyah). Semakin sering itu dilakukan maka anak-anak tidak punya banyak waktu untuk main diluar. Sikap taat beribadah inilah yang menjadi indikator dari akhlak. Akhlak merupakan kesadaran seorang hamba akan kewajiban beribadah pada Tuhannya. Sikap inilah yang akan dibangun dalam pendidikan berbasis masjid atau madrasah diniyah.

Dalam prakateknya anak-anak jadi terbiasa menjalankan kewajiban tanpa harus disuruh atau diperintah oleh orang tuanya. Kesadaran inilah bagian dari akhlak yang dibangun melalui pendidikan berbasis masjid.

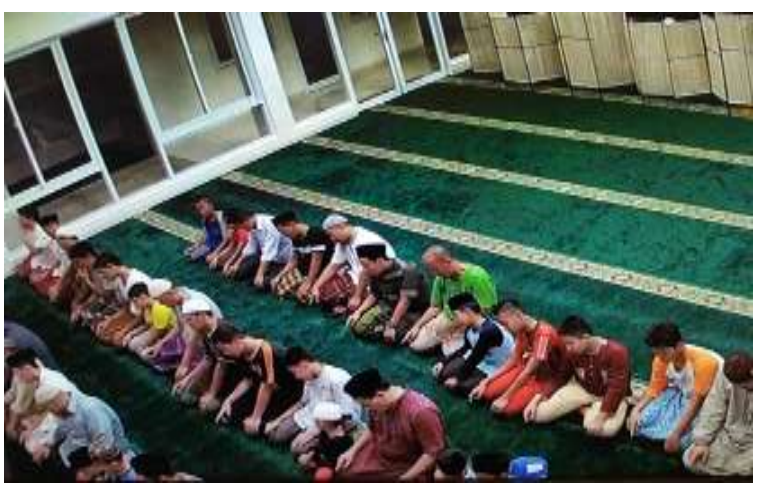

Gambar 3. Anak-anak sholat berjamah dengan orang dewasa

Gambar 3 diambil dari salah satu kegiatan sholat berjamaah. Anak-anak sudah terbiasa membaur dengan orang dewasa sedang melaksanakan sholat Isya. Kegiatan sholat berjamaah ini rutin dilakukan terutama waktu sholat magrib dan isya dan syukur Alhamdulillah anak-anak tertib sehingga tidak menggangu kekhusyuhan jamaah yang lainnnya.

Masjid dalam peradaban baru adalah masjid yang mampu membentuk spiritualitas manusia untuk mendapatkan nilai-nilai internal dan eksternal secara kompleks. Rasionalitas dan hidup yang pelik telah menjadikan manusia memiliki kehampaan hidup dalam dunia kepalsuan sehingga membutuhkan masjid untuk menemukan spritualitas [8]. 


\section{Masjid dan Pendidikan Anak}

Dalam syariat Islam anak belum memilki kewajiban untuk beribadah sampai usia baligh. Dimana usia yang menjadi kewajiban anak untuk beribadah dan sudah dikenakan hukum apabila anak meninggalkannya maka anak akan berdosa.

Menciptakan masjid ramah anak memang membutuhkan kesiapan manajemen, tata ruang dan kesadaran tinggi para jamaah, padahal anak juga memiliki hak guna terhadap masjid, adapun candaaan mereka yang dapat menganggu kenyamanan orang dewasa bisa diperingati dengan lemah lembut, tidak perlu ada bentakan, dihardik atau dengan cara-cara kasar lainnya yang dapat meninggal trauma sehingga membuat anak tidak mau lagi datang kemasjid. Hal ini dapat merugikan semuanya baik kita sebagai orang tua dan sebagai pengurus masjid, ketika yang diperlakukan hanya satu anak, tetapi yang lainnya melihat ini berpotensi terkena pada anak yang lainnya. Jika ini terjadi maka orang tua serta pengurus masjid menjadi gagal dalam menghasilkan masjid sebagai pusat peradaban.

Anak-anak merupakan penerus bagi keberlangsungan agama. Sudah saatnya para pengurus masjid dan para orang tua menjadikan masjid ramah terhadap anak dimana didalamnya ada suka cita dalam melakukan segala kegiatan baik ibadah serta dapat melakukan kegiatan belajar mengajar, sehingga masjid berkontribusi melahirkan generasi-generasi yang Islami.

\section{Meningkatkan Akhlak Anak Melalui Pendidikan Masjid/Madrasah Diniyah}

Di era kejayaan Islam masjid tidak hanya berfungsi hanya sebagai tempat ibadah saja. Namun juga sebagai tempat kegiatan intetelektual. J Pedersen dalam bukunya berjudul Arabic Book. Sejak awal perkembangannya, masjid memiliki kontribusi yang sangat penting dalam menghadirkan pendidikan di dunia Islam[9]. sepanjang sejarahnya masjid dan pendidikan Islam memang dua hal yang tidak dapat dipisahkan, masjid dan sekolah menjadi satu kesatuan. Sejak pertama kali berdiri masjid telah menjadi pusat kegiatan keIslaman, seperti sholat, berdakwa, mendiskusikan politik dan juga sekolah.

Akhlak berasal dari kata khuluq yang memilki arti budi pekerti, sikap, karakater, prilaku atau perangai yang baik. Menurut Ibnu Maskawaih aklah adalah keadaan jiwa seseorang yang mendorong melakukan perbuatan-perbuatan tanpa melalui pertimbangan akal terlebih dahulu. Sedang menurut Iman Al Ghozali akhlak adalah prilaku pada diri (sifat) yang tertanam dalam jiwa seseorang untuk mendorong perbuatan baik yang spontan tanpa memerlukan pertimbangan pikiran [10].

Oleh karena itu pendidikan akhlak pada anak harus segera dikenalkan sedini mungking, kejiwaan anak-anak yang masil bersih idealnya sudah di tamannkan, memalui pembiasaan datang kemasjid dan ikut terlibat dalam pembelajaran ini menjadi alternatif dimana anak belum tentu mendapatkan pendidikan serupa disekolah. Sekolah hanya mengepankan kognitif yang kecenderungan hanya mengedepankan kecerdasan berupa angka, sehingga pendidikan berbasis masjid bisa diandalakan untuk membantu anak meraih kedersaaan secara spiritual.

Ada beberapa materi pembelajaran yang dikembangan dalam masjid diantaranya, ada pelajaran fiqih, dimana anak-anak dalam mempelajari ilmu tata cara ibadah yang baik dan benar. Ilmu tajwid, anak-anak mempelajari ilmu kaidah membaca al qur'an serta hukum yang terdapat didalamnya. Ilmu sejarah kebudayaan Islam, dengan materi ini 
anak-anak dapat mengetahui tentang perjalanan sejarah Islam. Ada juga materi hadist yang isinya tuntunan untuk meningkat kualitas iman dan hubungan sosial, dan akhidah akhlak, ilmu ini menggabungkan antara keyakinan pada ketauhidan Allah SWT yang dapat diimplentasikan dalam kehidupan sehari-hari. Implementasi nilainilai ketauhidan inilah yang disebut dengan akhlakul karimah.

Materi pembelajaran ini yang selalu dijadikan rujukan pada pendidikan non formal berbasis masjid. Dalam upaya meningkatkan kualitas akhlak pada anak ini harus berikan secara berkala dan terus menerus. Anak yang sholeh menjadi dambaan bagi setiap orang tua, dengan demikian orang tua juga memiliki andil besar dalam mengantarkan anak-anak bagaimana kedepannya. Kesholehan pada anak lebih banyak didapatkan dimasjid. Pendalaman ilmu agama serta pengaktualisasinya merupakan perpaduan antara ibadah ritual dan sosial.

Hampir disemua masjid sudah mengembangkan pendidikan ini. Minimnya ilmu agama disekolah menjadi kelanjutan pendidikan yang tidak hanya didapat pada pendidikan formal. Dengan demikian masjid dapat diandalkan untuk menjadi alternatif pendidikan non formal dalam menghasilkan generasi yang memiliki akhkul karimah, dapat memilki tanggung jawab baik secara individu dan kolektif, berguna bagi masyarakat, lingkungan hingga sekup yang lebih luas yakni nusa dan bangsa.

\section{SIMPULAN}

Minimnya jam pembelajaran agama disekolah berpotensi membuat anak kurang mengetahui ilmu agama. Pendidikan diniyah atau pendidikan berbasis masjid dapat dijadikan alternatif untuk mengisi kekosongan jam pembelajaran agama yang kurang disekolah. Dengan mendorong anakanak belajar dimasjid dapat menumbuhkan kesadaran dan penegetahuan pada anak, bahwa hidup tidak hanya berkaitan dengan dunia saja akan tetapi ada juga kehidupan akhirat. Pemahaman agama yang didapat dimasjid dapat di implementasikan dalam bentuk kepribadian yang baik atau yang disebut akhlak Masjid tidak hanya dapat digunakan sebagai tempat ibadah semata, akan tetapi dapat dijadikan tempat belajar.

\section{DAFTAR PUSTAKA}

[1] Nurkhlolis. "Pendidikan Dalam Upaya Memajukan Teknologi", Jurnal Kependidikan, vol. 1, no. 1, 2013.

[2] Soelaman, Joesoef. Konsep Dasar Pendidikan non formal. Jakarta: Bumi Aksara. 1992.

[3] Sodikin, Ali. dkk, Sejarah Peradaban Islam Dari Masa Klasik Hingga Modern. Yogyakarta: LESFI. 2012.

[4] Mohammad E. Ayub, Manajemen Masjid. Jakarta: Gema Insani. 2005.

[5] Nurjamilah,Cucu. "PAUD dan Masjid”. Al-Hikmah: Jurnal Dakwah, vol. 12, no 2. 2018.

[6] Moleong J lexy, Metode Penelitian Kualitatif, Edisi Revisi, Cetakan ke 13 Bandung, Remaja Rosdakarya, 2013

[7] Sugiono, Metode Penelitian Kuantitatif dan Kualitatif R\&D, Bandung, Alfabeta, 2012

[8] Arif Hidayat, Masjid Dalam Menyikapi Peradaban Baru, Ibda, Jurnal Kebudayan Islam,vol.12, no.1. 2014

[9] Repulika, khazanah. Peran Masjid dalam Peradaban Islam, 20 Mar 2009

[10] Rosihon Anwar, Akhlak Tasawuf. Bandung:CV Pustaka Setia. 2010 